\title{
Supply chain and marketing of sea grapes, Caulerpa racemosa (Forsskål) J. Agardh (Chlorophyta: Caulerpaceae) in Fiji, Samoa and Tonga
}

\author{
C. Morris • S. Bala • G. R. South • J. Lako • M. Lober • \\ T. Simos
}

Received: 21 October 2013 / Revised and accepted: 24 January 2014 / Published online: 16 February 2014

(C) The Author(s) 2014. This article is published with open access at Springerlink.com

\begin{abstract}
This report describes for the first time the supply chain of Caulerpa racemosa in three Pacific Island countries. The harvesting and marketing of $C$. racemosa are important subsistence activities for villagers in Fiji and Samoa, less so in Tonga. At least 150 harvesters are involved in Fiji, some 100 in Samoa and only a handful in Tonga. The annual combined crop is of some $123 \mathrm{t}$ valued at around US\$266,492. In Fiji, it is projected that supply does not meet local demand and there is a potential export market that is currently operating at a pilot project level. In Samoa, the supply is considered adequate for the current market. In Tonga, harvesting is carried out by a few families and supplies a niche market in that country. The possibilities of field cultivation of Caulerpa have been explored but, at present, with only limited success in Samoa. The supply chain is simple in all three countries, and only in Fiji are middlemen involved in the distribution process. The limitations for marketing include the fact that only a few sites
\end{abstract}

Electronic supplementary material The online version of this article (doi:10.1007/s10811-014-0254-1) contains supplementary material, which is available to authorized users.

C. Morris $(\bowtie) \cdot$ S. Bala

Institute of Marine Resources, School of Marine Studies, University of the South Pacific, Suva, Fiji

e-mail: morris_c@usp.ac.fj

G. R. South

School of Marine Studies, Faculty of Science, Technology and

Environment, University of the South Pacific, Alafua, Samoa

J. Lako

Faculty of Science, Technology and Environment, University of the South Pacific, Suva, Fiji

M. Lober

Private Consultant, Apia, Samoa

T. Simos

School of Agriculture, Food and Wine, University of Adelaide,

Adelaide, Australia supply most of the crop in all the three countries, that all sites need to be conserved through sustainable harvesting methods, the short shelf life of the crop and a lack of information on the carrying capacity of harvest sites. Caulerpa remains a crop that fulfils a niche market but has the potential to be scaled up for additional livelihood development in the future.

Keywords Harvesting $\cdot$ Marketing $\cdot$ Supply chain $\cdot$ Fiji . Samoa $\cdot$ Tonga

\section{Introduction}

The edible seaweed Caulerpa racemosa (Forsskål) J. Agardh (Class Bryopsidiophceae, Order Bryopsidales, Family Caulerpaceae) is widely consumed in the Pacific Islands and has been the subject of several reports on its harvesting and consumption in Fiji (South 1993a, 1993b, 1993c; South and Pickering 2006). Taxonomic studies on the genus Caulerpa were undertaken for Fiji and Samoa by South and N'Yeurt (1993) and South and Skelton (2003). The potential for the post-harvest treatment and export of $C$. racemosa was examined by Chamberlain (1997) and Chamberlain and Pickering (1996). The general market and food potential of C. racemosa were included in the reports of Novaczek (2001) and Pickering and Mario (1999). The supply chain of sea grapes in Fiji is described by Morris and Bala (2012). Previous reports have identified that the industry is based on harvesting mostly at the subsistence level, where the income derived supplements fishing, farming and other activities. There is no information available on the sustainability of the crop or the contribution that it makes to household incomes at the village level.

C. racemosa is one of 86 valid species worldwide (Guiry and Guiry 2011; www.AlgaeBase.org). In the tropical Pacific, there are more than 30 species, and many of them have a pantropical distribution. Fiji has a rich Caulerpa biodiversity, 
with 32 species known, one of which is endemic (South and Skelton 2003), but only 9 species have been reported from Samoa (Skelton and South 2007; Skelton and South 2014). The number of species found in Tonga is not yet recorded.

Although Caulerpa is widely consumed in the Pacific Islands and is the basis of a subsistence fishery, information on its supply chain, marketing and value is very scarce.
In this paper, we report on the supply chain in Fiji, Samoa and Tonga.

\section{Materials and methods}

Supply chain and marketing surveys were carried out using semi-structured interviews based on questionnaires developed
Fig. 1 Supply chain maps for a Fiji, b Samoa and c Tonga, with the numbers representing the harvesting sites/villages (with exception to Tonga, where the harvesting sites are represented by the letter $X$ and villages represented using numbers) and alphabets representing the marketing sites. Marketing sites are hyphenated with numbers indicating the source of seagrapes at respective outlets. Fig. 1a shows the Fiji harvesting sites/ villages: 1 Gunu, 2 Namuimada, 3 Navolau, 4 Vatutavui, 5 Lomowai, 6 Vatulele, 7 Vusama, 8 Sasake, 9 Lakeba, 10 Dromoniku; and marketing sites: $a$ Lautoka, $b$ Nadi, $c$ Suva, $d$ Nausori, $e$ Rakiraki, $f$ Mana Island, $g$ Tavua, $h \mathrm{Ba}$, $i$ Sigatoka, $j$ Labasa, $k$ Savusavu. Fig. $1 \mathrm{~b}$ shows Samoa harvesting sites/ villages: 1 Asaga, 2 Lano, 3 Faga, 4 Vailoa, 6 Satumalufilufi, 7 Mulifanua, 8 Lalovi, 9 Satapuala, 10 Leauva'a; and marketing sites: $a$ Fugalei, $b$ Apia fish market, $c$ Salelologa, $x$ roadside sales. Fig 1c shows Tonga harvesting villages: 1 Patangata, 2 Holeva, 3 Kaloa; and marketing sites: $a$ Nuku'alofa, $b$ Vava'u

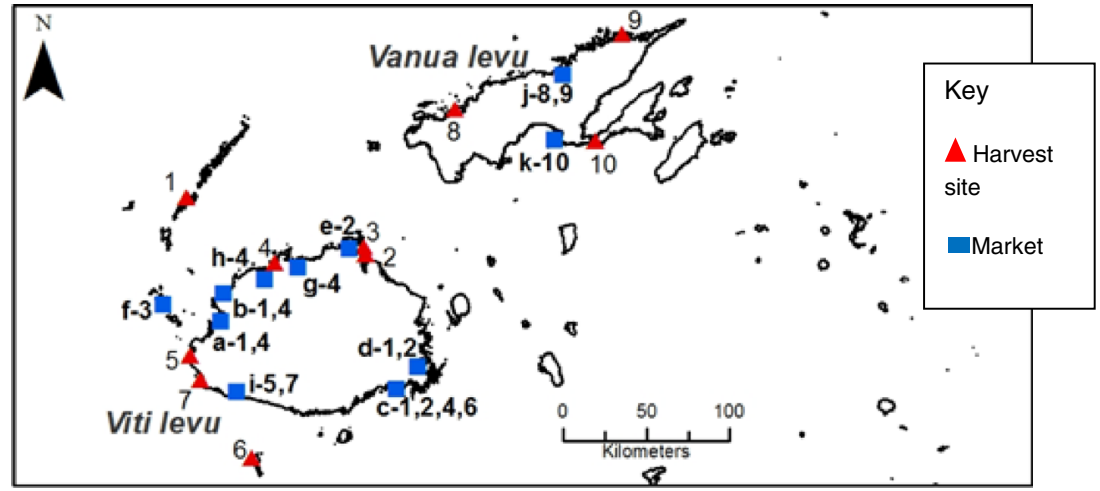

A Harvesting and marketing sites for Caulerpa in Fiji

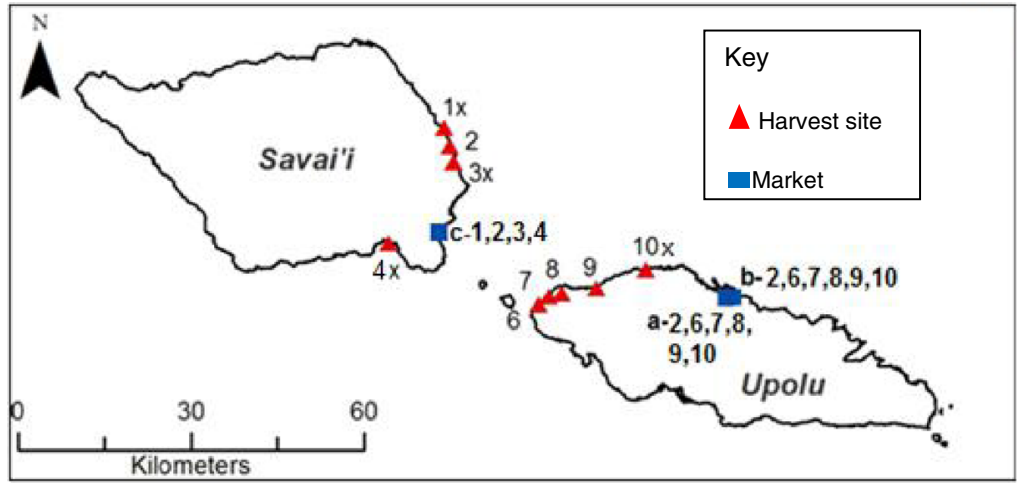

B Harvesting and marketing sites for Caulerpa in Samoa

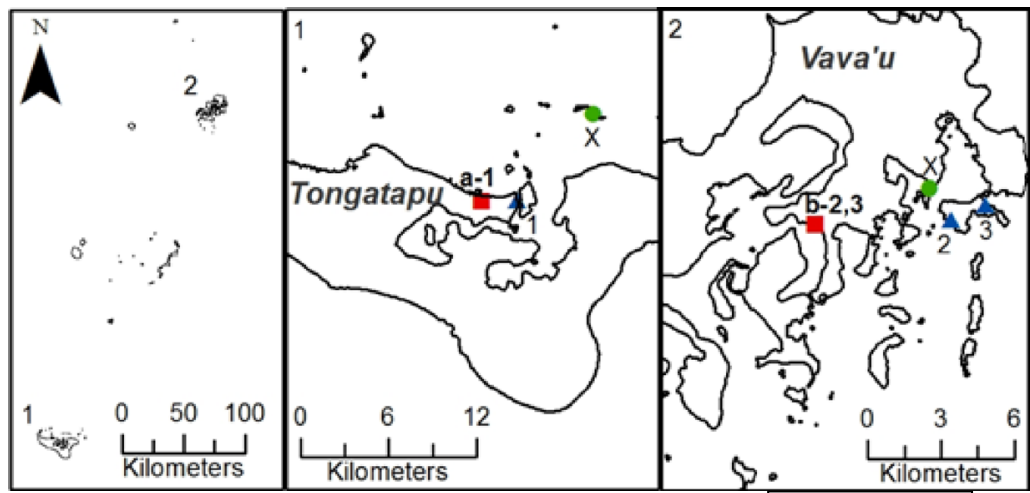

C Harvesting and marketing sites for Caulerpa inTonga

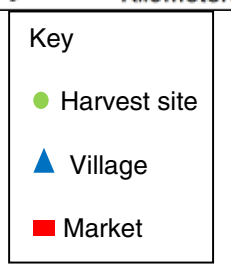


by fisheries personnel in Fiji and Samoa. The questionnaires were either translated into the local languages or were carried out by surveyors speaking in the local language (Annex 1). A total of 30 people were interviewed in the three target island countries.

The fisheries staff in Fiji and Tonga do not discriminate between Caulerpa and other inshore fishery products in their annual statistic reports. In Samoa, however, reliable data are collected and regularly maintained on a national Access database. The Samoa fishery survey methods include

- Production data recorded from vendors at the Fugalei (Upolu) and Salelologa (Savaii) markets and the roadside, from surveys conducted three times a week. Roadside surveys are carried out on Upolu Island only. The bulk of harvested production each year is naturally sold at the Fugalei produce market in the capital followed by Salelologa market and least along the roadside (Fig 1).

- Vendors are asked which village they are from, how much seaweed they are selling on the day, and the price. The total production is estimated from a weighted average raised by a factor calculated regularly.

Harvesting and supply chain data gathered from selected harvesting sites in Fiji, Samoa and Tonga were analysed using probability and trend analysis.

\section{Results}

Detailed background information is provided in South et al.(2011); we are not aware of any previous studies on the supply chain and marketing of $C$. racemosa in the Pacific. We are also not aware of any work on the distribution, abundance and resource-carrying capacity of harvesting sites for C. racemosa anywhere in the Pacific. The impact of harvesting to determine long-term sustainability and capacity for further exploitation has not been investigated.

Table 1 Annual production and revenue from Caulerpa harvesting and sales in Fiji in 2012

\begin{tabular}{lll}
\hline Site & $\begin{array}{l}\text { Total Production } \\
\text { per annum (t) }\end{array}$ & $\begin{array}{l}\text { Total Revenue } \\
(\mathrm{FJD})\end{array}$ \\
\hline Yasawa & 75.6 & 129,600 \\
Sigatoka & 2.7 & 24,300 \\
Rakiraki & 4.8 & 24,390 \\
Tavua & 9.0 & 27,000 \\
Labasa & 14.6 & 41,040 \\
Savusavu & 3.2 & 9,000 \\
Total & 110 & FJD 255,330 \\
& & (US\$ 141,632) \\
\hline
\end{tabular}

Table 2 Summary of production and value of Caulerpa harvested in Samoa in 2010

\begin{tabular}{lll}
\hline Site & $\begin{array}{l}\text { Total Production } \\
\text { per annum (t) }\end{array}$ & Total Revenue (SAT) \\
\hline Leauvaa & 3 & 44,133 \\
Satapuala & 0.76 & 11,913 \\
Mulifanua & 2.5 & 77,698 \\
Satuimalufilufi & 0.64 & 9,615 \\
Lalovi & 0.93 & 14,264 \\
Total & 7.83 & 157,623 \\
& & (USD 69,196) \\
\hline
\end{tabular}

Source: Samoa Fisheries Division

Marketing, quantities and value

Fiji

The harvesting and marketing information for Caulerpa in Fiji is presented in Fig. 1A and Table 1. Approximately $75 \%$ of the crop is from the Yasawa Islands. Caulerpa is sold in a number of markets, with the main municipal market located in Suva. In Fiji, Caulerpa is sold by portion (heaps), at prices ranging from FJ $\$ 2.00-4.00^{1}$ per heap, the weight of which ranges from 250 $300 \mathrm{~g}$. The plants are generally offered to customers on plastic plates, usually accompanied by a small plastic bag or cup of fermented coconut and fresh chilli. Whilst all municipal markets lack refrigeration facilities, Suva vendors make considerable effort to maintain freshness by splashing sea water on the bagged stock until ready for display.

The peak marketing days of Caulerpa in Fiji are Fridays and Saturdays to prepare for consumption on Sunday. Fresh, harvested stock arrives in the main markets (Suva and Lautoka) by Thursday afternoon. On Viti Levu, some harvesters do their own retailing but generally, most stock is sold direct to wholesalers and market vendors in Lautoka, Nadi, Sigatoka and Suva. In contrast, most harvesters located on Vanua Levu, Fiji's second largest island, retail their own stock directly with little wholesaling.

\section{Samoa}

A summary of harvesting and marketing sites, and production and value of Caulerpa in Samoa is shown in Fig. 1B and Table 2. Plants are also sold in heaps (known as ofu limu in Samoan) of up to $350 \mathrm{~g}$ in weight, wrapped either in foil or in breadfruit and coconut leaves. The selling price ranged from SAT\$8 to 10 per heap (Lober 2011).

Vendors in Samoa may sell between 40 and 80 heaps per week. Transport to market is usually by a combination of bus and

\footnotetext{
${ }^{1}$ Approximate exchange rates: FJD1.00 $=$ US $\$ 0.559$; SAT1.00 $=$ US\$0.439;TOP $1.00=$ US\$0.55.
} 
Table 3 Summary of production and value of Caulerpa in Nuku'alofaTonga in 2012

\begin{tabular}{llll}
\hline Site & $\begin{array}{l}\text { Total production } \\
\text { per annum (t) }\end{array}$ & $\begin{array}{l}\text { Revenue per } \\
\text { annum (TOP) }\end{array}$ & $\begin{array}{l}\text { Average value } \\
\text { per kg (TOP) }\end{array}$ \\
\hline $\begin{array}{l}\text { Nuku'alofa } \\
\text { (Tongatapu) }\end{array}$ & 2.5 & 41,433 & 17 \\
$\begin{array}{l}\text { Vava'u } \\
\text { Total }\end{array}$ & 0.9 & 5,760 & 6 \\
& 3.4 & $\begin{array}{l}47,193 \\
\text { (USD 26,735) }\end{array}$ \\
\hline
\end{tabular}

ferry boat where orders are required to be sourced from the island of Upolu. Orders from caterers and hotels occur occasionally, and hoteliers and restaurateurs pick up their own orders from harvesters in Savai'i. At Lano, harvesters supply orders for Upolu caterers and hoteliers usually up to 20 ofu limu at one time. These are taken by bus to Salelologa wharf by the harvester or a relative, then by a combination of ferry boat to Upolu, bus to
Fugalei market and finally taxi to its final destination. Costs associated with this supply method amount to SAT\$48.00, inclusive of return modes of transport (fares by bus, ferry and taxi).

According to fisheries database records, Caulerpa was harvested from a total of 47 villages on Upolu and Savaii islands from 2005 to 2010 which showed a stable average trend. Although a stable value was maintained over the last 4 years, the first 2 years showed a lower value. The lowest value of Caulerpa in 2006 (SAT\$91,337) equated to smaller harvests, and this shortfall in supply led to an increased average price of SAT $\$ 15 \mathrm{~kg}^{-1}$ in later years.

\section{Tonga}

A summary of the harvesting and marketing sites, and quantities and value of the crop is presented in Fig. 3 and Table 3. Caulerpa is sold in only two municipal markets in Tonga, Nuku'alofa and Vava'u Islands. There are only two families
Fig. 2 Industrial supply chain map for Caulerpa-Fiji
HARVESTING

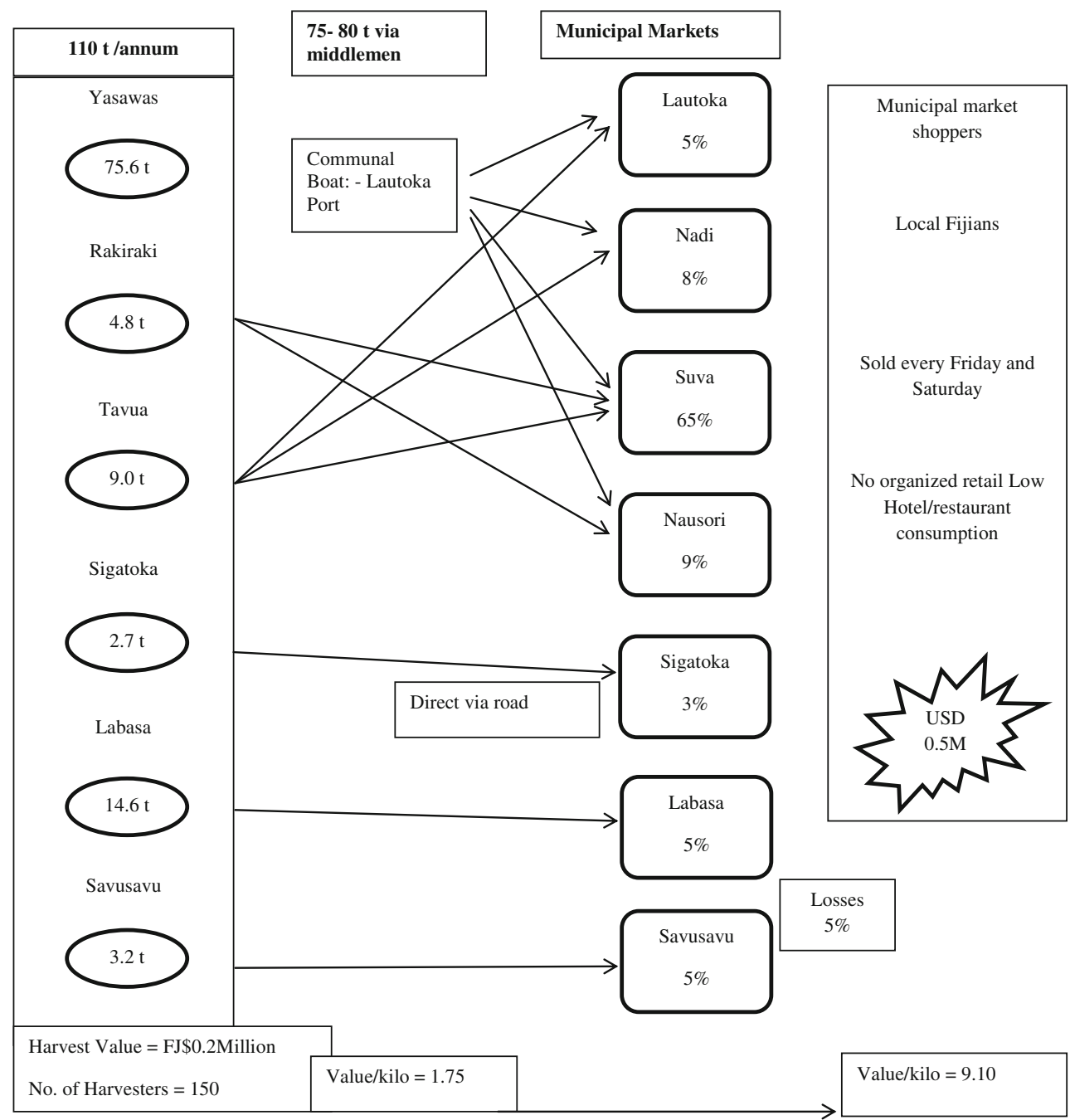


from the village of Patangata supplying the Nukualofa market on a daily basis (except Sunday). The two families have only one harvesting site which is the reef flat between Onevai and Onevau Island. The harvesters sell their own produce and there are no middleman involved.

There are two villages involved in Caulerpa harvesting and sales in Vava'u: the Holeva Village with two families involved and the Koloa village with only one family involved. Unlike Nukualofa, sales are only done in the weekend, whereby the family from Koloa sells on Fridays and Saturdays all year around, and the families from Holeva sells on Saturdays but only for 6 months (during peak season) per year.

The market and supply chains

The supply chains in Fiji, Samoa and Tonga are shown in Figs. 2, 3 and 4 and Tables 1-3, respectively. From surveys conducted at ten sites in six areas of Fiji, a total of some 150 harvesters (part-time and full-time) were recorded. Production ranged from 5 to $2,100 \mathrm{~kg}^{\text {week }}{ }^{-1}$, with an average of $323 \mathrm{~kg}$ week $^{-1}$. The main production areas were the Yasawa Islands, followed by Labasa, Tavua and Rakiraki.

Caulerpa harvesting and sales provide a part-time subsistence occupation for many villagers in Fiji and Samoa, with a potential income of more than FJ\$200 per week for harvesters. The industry provides only a small proportion $(<1.0 \%)$ of the overall national income from the inshore fishery, and Caulerpa sales are overshadowed by sales of other seaweeds in Fiji (South 1993b).

Fig. 3 Industrial supply chain map for Caulerpa - Samoa
According to Bala and Finau (2012), the annual production in Tonga was $3.4 \mathrm{t}$ (Nuku'alofa $2.5 \mathrm{t}$, Vava'u $0.9 \mathrm{t}$ ) with a market value of TOP47,193 (Table 3).

\section{Discussion}

The combined annual Caulerpa crop for Fiji, Samoa and Tonga amounts to some $123 \mathrm{t}$, valued at US\$266,492. There are some important aspects of the industry that need to be examined. The carrying capacity of the main harvesting beds has not been studied, and the population density and biomass at these sites are not yet known. The careful conservation of harvesting sites (as in the Yasawa Islands in Fiji) over long periods of time by local villagers may be a good measure allowing predictable harvesting. Sustainable harvesting (i.e. not removing the runners) is another important practice carried out by most harvesters in Fiji and Samoa, but not in Tonga. The introduction of improved post-harvest treatment by the use of proper wound-healing technology would prolong the life of the crop from harvesters to consumers.

The fact that harvesting of Caulerpa is limited to a few main sites where the resource grows readily and is easily and safely accessible to harvesters in coastal communities may mean that the industry is potentially vulnerable to loss of product. This loss may be due to the combined impacts of unsustainable harvesting and natural phenomena such as storm surges and cyclones, resulting in the sites becoming unproductive. A preliminary result from an ongoing Fiji

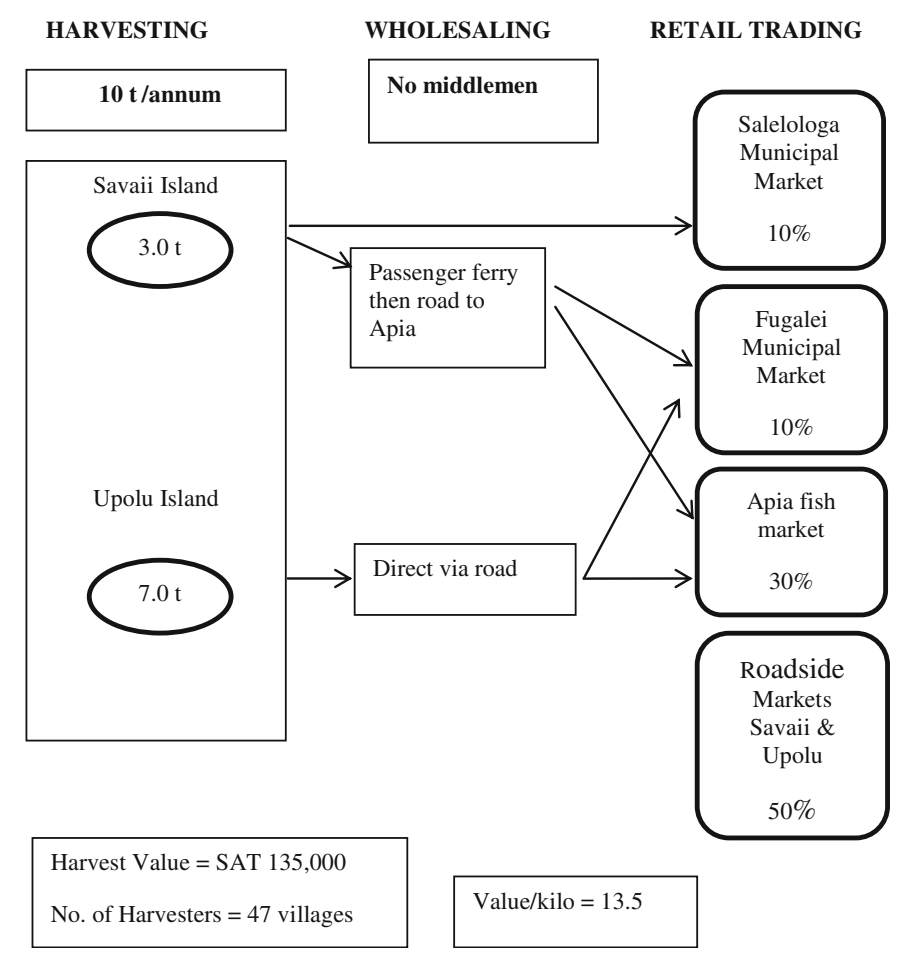

CONSUMERS

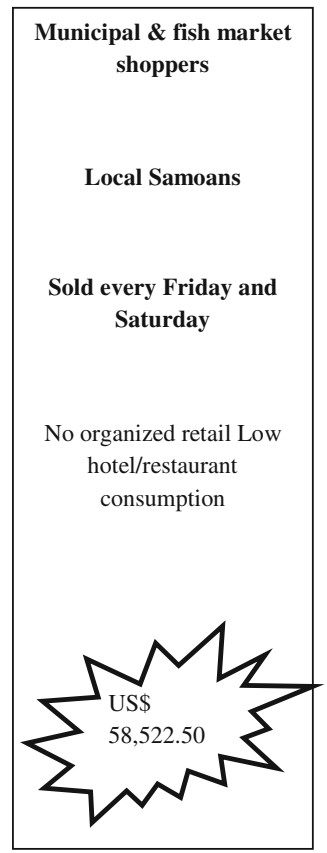


Fig. 4 Industrial supply chain map for Caulerpa - Tonga
HARVESTING

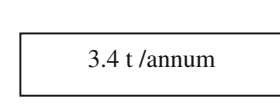

WHOLESALING

No middlemen
RETAIL TRADING
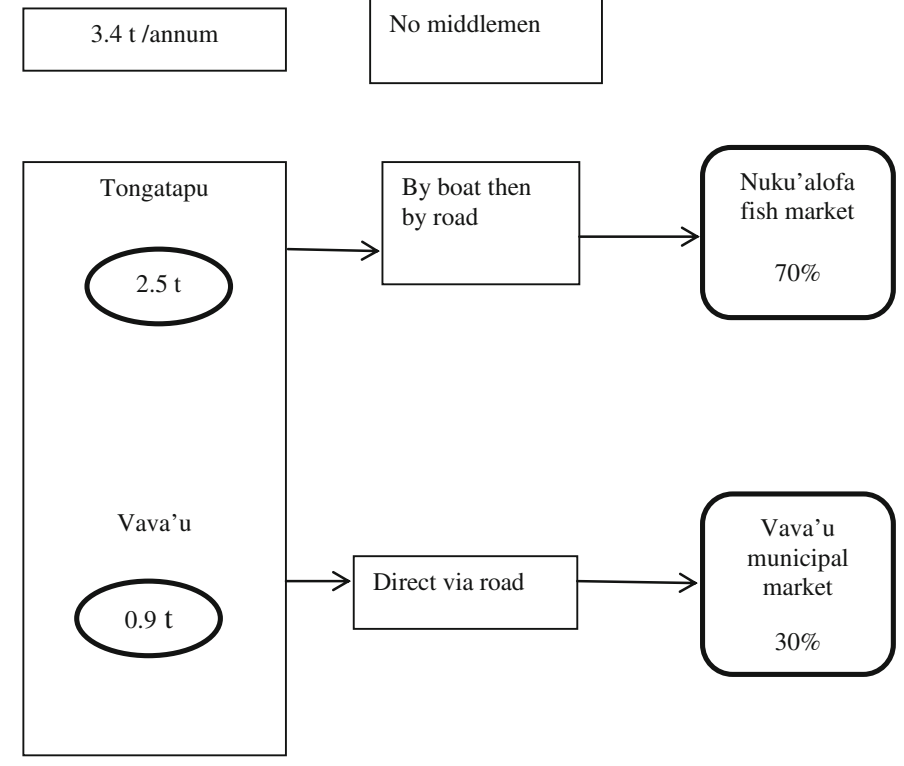
No. of Harvesters $=5$ families
Value $/$ kilo $=13.8$ biomass survey has shown that this has been the case with Rakiraki. Conservation of sites is to a certain extent in the hands of the harvesters themselves, but they are not formally protected. Harvesting is part of a traditional activity which for most includes inshore gleaning for shells, sea cucumber and fishing for the daily family meal.

Compared with other commodities, the supply chains are simple, and only in Fiji are middlemen routinely used. The crop goes directly to market with a 3-day shelf life due to limitations of being able to provide wound healing as a postharvest process. Shelf life could be substantially increased if harvesters were to use an appropriate wound-healing methodology such as holding in aerated seawater for up to $48 \mathrm{~h}$ following harvesting. Roadside sales do not routinely occur in Fiji, but they are common in Samoa on both of the main islands. The lack of sustainable harvesting at some sites is a potential threat to the long-term survival of the beds. The market supply chains show that the loss of crop occurs during handling between harvesters and consumers. This is partially a result of inadequate quality control. The port and the market serve as the consolidation point for middlemen who then carry out the distribution to other local markets and roadside stalls and in some case to some resorts.

Sustainability of the Caulerpa industry in the three island countries will depend on collection of more data with regards to carry capacity of important harvesting sites, identification of new potential sites for both wild and farm harvests and through raising awareness and training both harvesters and fisheries officers on management issues. In Samoa, some pilot trials to cultivate the local $C$. racemosa have been carried out on Upolu Island in collaboration with Samoa fisheries (Dr. N Paul, personal communication 2011). This method uses $1-\mathrm{m}^{2}$ shallow trays with double layers of netting on the bottom: the Caulerpa runners are placed between the two layers, allowing the shoots to grow through when the trays are anchored in shallow water.

Given the short shelf life and the many critical control points determined during preliminary surveys along the chain (especially since markets are up to $100 \mathrm{~km}$ away), it would be worthwhile to conduct a proper Hazard Analysis and Critical Control point (HACCP) analysis of the cold chain in order to determine the best methods of intervention. This would be the focus of future research.

Acknowledgments Sincere thanks to Mr. Jiuta Waqavonovono of the Commissioner Western Office, Fiji, for being the main liaison with the villages in Western and Northern Division. Many thanks to staff of District Office: Rakiraki, Tavua, Sigatoka, Labasa and Savusavu who either assisted in facilitation of village visits or accompanied the survey team to the sites.

We also wish to thank the staff of Ministry of Fisheries and Forests (Fiii) who assisted in facilitating activities and assisting in data collection: Eloni Takali, Shalendra Singh and Silina Seruilumi, also Marlyin Vilison 
from Savusavu for assisting in data collection and providing photos for North. We also acknowledge the support and information from Ms. Shamron Pickering from Pacific Seaweed Ltd.

Special thanks to Ms. Prerna Chand and Mr. Edgar Pollard for their assistance in mapping of harvesting sites and markets in Fiji.

We thank Ms. Joyce Ah Leong and her staff at the fisheries division in Samoa for assistance at all stages of the surveys and for assistance with translation of questionnaires.

Open Access This article is distributed under the terms of the Creative Commons Attribution License which permits any use, distribution, and reproduction in any medium, provided the original author(s) and the source are credited.

\section{References}

Bala S, Finau M (2012) Supply chain analysis of sea grapes (Caulerpa racemosa) in Tonga. Preliminary report, unpublished. Institute of Marine Resources, the University of the South Pacific, Suva, Fiji.

Chamberlain A (1997) Export potential of the edible seaweed Caulerpa racemosa from the Pacific. Project 6607-6301-70766-00. The University of the South Pacific, Fiji.

Chamberlain A, Pickering T (1996). Post-harvest handling of Caulerpa racemosa for artisanal and export fisheries in Fiji. Manuscript, unpubl.

Guiry MD, \& Guiry GM (2011). AlgaeBase. World-wide electronic publication, National University of Ireland, Galway.

Lober M(2011) Limu fuafua (seagrapes) in Samoa. Unpublished report. $15 \mathrm{pp}$.
Morris C, Bala S (2012) Supply chain of seagrapes (Caulerpa racemosa) in Fiji. Unpublished report, Institute of Marine Resources, the University of the South Pacific, Fiji. 21 pp.

Novaczek I (2001) A guide to the edible and medicinal sea plants of the Pacific. The University of the South Pacific and the Secretariat for the Pacific Community. 48 pp

Pickering T, Mario S (1999) Survey of commercial seaweeds in South-East Viti Levu (Fiji Islands). A preliminary study on farming potential of seaweed species present in Fiji. FAO South Pacific Aquaculture Development Project (Phase 11). Food and Agriculture organisation of the United Nations (GCP/ RAS/116/JPN).43 pp.

Skelton PA, South GR (2007) The benthic marine algae of the Samoan Archipelago, South Pacific with emphasis on the Apia District. Nova Hedwigia Beih 132:1-350

Skelton PA, South GR (2014) Marine Plants of Samoa. University of the South Pacific Suva. 146 pp

South GR (1993a) Seaweeds. In: Wright A, Hill L (eds) University of the South Pacific. Institute of Pacific Studies, Suva, pp 683-710

South GR (1993b) Edible seaweeds of Fiji: an ethnobotanical study. Bot Mar 36:335-349

South GR (1993c) Edible seaweeds - an important source of food and income to indigenous Fijians. NAGA, the ICLARM Quarterly. April-July 1993: 4-6.

South GR, N'Yeurt ADR (1993) Contributions to a catalogue of the marine algae of Fiji. II. Caulerpa and Caulerpella (Chlorophyta). Micronesica 26:107-136

South GR and Pickering T (2006) The seaweed resources of the Pacific Islands. World Seaweed Resources. (ed. Critchley AT Ohno M., and D.B. Largo. DVD Rom.

South GR, Skelton P (2003) Additions and revisions to Caulerpa (Chlorophyceae, Caulerpaceae) from the Fiji Islands, South Pacific. Aust Syst Bot 16:534-548

South GR, Morris C, Bala S, Lober M (2011) Scoping study for sea grapes in Fiji, Samoa and Tonga. Pacific Agribusiness Research for Development Initiative (PARDI) Project 2010/002. Report. 37 pp. 